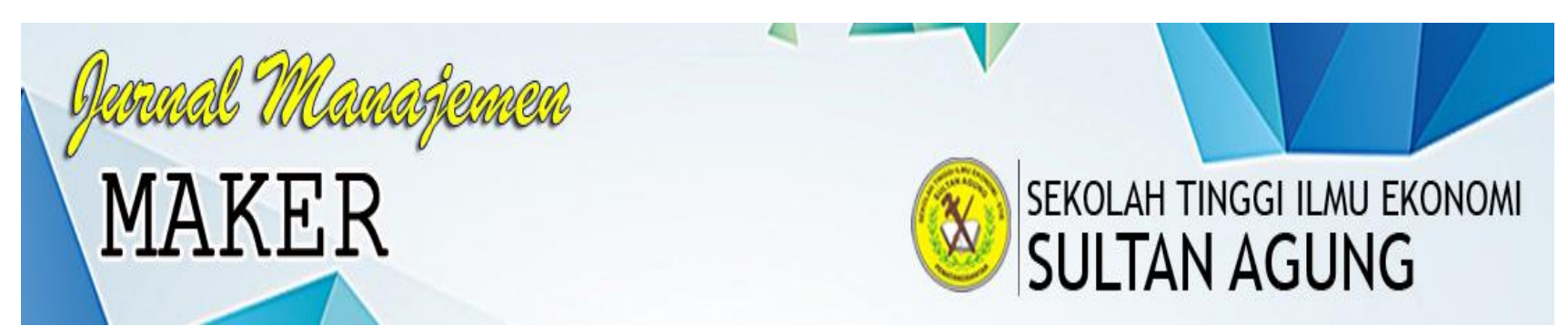

\title{
PENGARUH KARAKTERISTIK INDIVIDU DAN LINGKUNGAN KERJA TERHADAP \\ KINERJA PEGAWAI PADA BADAN PENGELOLAAN PAJAK DAN RETRIBUSI DAERAH UPT SAMSAT PEMATANGSIANTAR
}

\author{
Oleh: \\ Devi Desyinta \\ S1 Manajemen \\ Darwin Lie, Efendi, Debi Eka Putri
}

\begin{abstract}
Abstrak
Hasil penelitian ini dapat disimpulkan sebagai berikut: 1. Karakteristik individu, lingkungan kerja dan kinerja pegawai sudah baik. 2. Hasil analisis regresi yaitu $\hat{Y}=20,910+$ $0,816 \mathrm{X}_{1}+0,399 \mathrm{X}_{2}$ artinya karakteristik individu dan lingkungan kerja berpengaruh positif terhadap kinerja pegawai. 3. Hasil analisis korelasi diperoleh nilai $r=0,799$, artinya terdapat hubungan yang kuat dan positif antara karakteristik individu dan lingkungan kerja terhadap kinerja pegawai 4. Diperoleh nilai koefisien determinasi dapat dijelaskan tinggi rendahnya kinerja pegawai $63,90 \%$, dan sisanya $36,10 \%$ dijelaskan oleh faktor lainnya yang tidak dibahas dalam penelitian ini. Dari hasil pengolahan dan perhitungan kuesioner, penulis mendapatkan kesimpulan bahwa karakteristik individu dan lingkungan kerja yang dilakukan Badan Pengelolaan Pajak dan Retribusi Daerah UPT SAMSAT Pematangsiantar berpengaruh positif dan signifikan terhadap kinerja pegawai. Hal ini dibuktikan melalui uji hipotesis secara simultan, dimana hasil uji $f_{\text {hitung }}(36,214)>f_{\text {tabel }}(3,23)$ dengan taraf signifikansi $0,000<0,05$.
\end{abstract}

Kata Kunci: Karakteristik Individu, Lingkungan Kerja, dan Kinerja Pegawai

\section{Abstract}

The result of this study can be summarized as follows: 1. Individual Characteristic and Work Environment on Employee Performance are good. 2. The analysis regression is $\hat{\mathrm{Y}}=$ $20,910+0,816 \mathrm{X}_{1}+0,399 \mathrm{X}_{2}$ have a positive influence between individual characteristic and work environment to employee performance. 3. The correlation result of $r=0,799$, the analysis correlation have a moderately high and positive correlation between individual characteristic, work environment with the employee performance. 4. The result of coefficient of determination can be explained the level of employee performance is $63.90 \%$, and the remaining $36.10 \%$ is explained by other factors not discussed in this study. From the results of the processing and calculation of the questionnaire, the authors concluded that the individual characteristics and work environment conducted by the Badan Pengelolaan Pajak dan Retribusi Daerah UPT SAMSAT Pematangsiantar had a positive and significant effect on employee performance. This is evidenced by simultaneous hypothesis testing, where the results of the test are calculated (36,214)> ftabel (3.23) with a significance level of 0,000 <0,05.

\section{Keywords: Individual Characteristic, Work Environment, and Employee Performance}

\section{A. PENDAHULUAN}

\section{Latar Belakang Masalah}

Suksesnya suatu organisasi tergantung dari tenaga kerja yang diperlukan. Sumber daya manusia merupakan satu aset yang paling berharga yang dimiliki oleh suatu instansi, organisasi atau perusahaan. Oleh sebab itu, banyak perusahaan yang selalu berusaha meningkatkan kualitas sumber daya manusia.

Kantor Badan Pengelolaan Pajak dan Retribusi Daerah UPT SAMSAT Pematangsiantar adalah salah satu Unit Pelaksanaan Teknis Dinas Pendapatan Daerah yang mengharapkan kinerja yang optimal, khususnya menjalankan tugas dan 
tanggungjawabnya dalam hal pengelolaan Pendapatan Asli Daerah. Tugas dari Badan Pengelolaan Pajak dan Retribusi Daerah UPT SAMSAT Pematangsiantar adalah melayani masyarakat dalam hal pengurusan Surat Tanda Nomor Kendaraan Bermotor (STNKB), pemungutan Pajak Kendaraan Bermotor (PKB), Bea Balik Nama Kendaraan Bermotor (BBN-KB) dan Sumbangan Wajib Dana Kecelakaan Lalu Lintas Jalan (SWDKLLJ).

Kinerja pegawai sangat menentukan berhasil atau tidaknya perusahaan/instansi tersebut dalam mencapai tujuannya. Kinerja merupakan hasil kerja secara kualitas dan kuantitas yang dicapai oleh seorang pegawai dalam melaksanakan fungsinya sesuai dengan tanggungjawab yang diberikan kepadanya.

Dalam mencapai tujuan organisasi kinerja pegawai pada Badan Pengelolaan Pajak dan Retribusi Daerah UPT SAMSAT Pematangsiantar diatur dalam PP No. 46 Tahun 2011 yaitu Sasaran Kerja Pegawai (SKP) dan Perilaku Kerja (PK). Sasaran Kerja Pegawai (SKP) terdiri dari dimensi kualitas kerja, kuantitas kerja, biaya dan waktu. Sedangkan pada Perilaku Kerja (PK) terdiri dari dimensi orientasi pelayanan, integritas, komitmen, disiplin, kerja sama dan kepemimpinan. Berikut ini adalah kinerja 44 orang Pegawai Negeri Sipil (PNS) pada Badan Pengelolaan Pajak dan Retribusi Daerah UPT SAMSAT Pematangsiantar. Adapun fenomena kinerja pegawai Badan Pengelolaan Pajak dan Retribusi Daerah UPT SAMSAT Pematangsiantar adalah sebagai berikut:

\section{Tabel 1}

Presentase Kinerja Pegawai UPT SAMSAT Pematangsiantar

\begin{tabular}{|c|c|c|c|c|c|c|}
\hline $\begin{array}{c}\text { Dimensi } \\
\text { Kinerja } \\
\text { Pegawai }\end{array}$ & $\begin{array}{c}\text { S } \\
\text { B }\end{array}$ & B & CB & TB & STB & $\begin{array}{c}\text { Jumla } \\
\text { h }\end{array}$ \\
\hline $\begin{array}{c}\text { Sasaran } \\
\text { Kerja } \\
\text { Pegawai }\end{array}$ & $\begin{array}{c}30 \\
\%\end{array}$ & $\begin{array}{c}50 \\
\%\end{array}$ & $\begin{array}{c}15 \\
\%\end{array}$ & $5 \%$ & $0 \%$ & $100 \%$ \\
\hline $\begin{array}{c}\text { Perilaku } \\
\text { Kerja }\end{array}$ & $\begin{array}{c}30 \\
\%\end{array}$ & $\begin{array}{c}40 \\
\%\end{array}$ & $\begin{array}{c}25 \\
\%\end{array}$ & $5 \%$ & $0 \%$ & $100 \%$ \\
\hline $\begin{array}{c}\text { Rata- } \\
\text { rata }\end{array}$ & $\begin{array}{c}\mathbf{3 0} \\
\mathbf{\%}\end{array}$ & $\begin{array}{c}\mathbf{4 5} \\
\mathbf{\%}\end{array}$ & $\begin{array}{c}\mathbf{2 0} \\
\mathbf{\%}\end{array}$ & $\mathbf{5 \%}$ & $\mathbf{0 \%}$ & $\begin{array}{c}\mathbf{1 0 0} \\
\mathbf{\%}\end{array}$ \\
\hline
\end{tabular}

Sumber: Hasil Wawancara Kepala Subbagian Tata Usaha Badan Pengelolaan Pajak dan Retribusi Daerah UPT SAMSAT Pematangsiantar, Mei (2018).

Berdasarkan tabel 1 di atas dapat diketahui bahwa kinerja pegawai pada Badan Pengelolaan Pajak dan Retribusi Daerah UPT SAMSAT Pematangsiantar masih belum optimal. Hal ini dapat dilihat dari beberapa dimensi masih ada kategori cukup baik dengan persentase rata-rata $20 \%$ dan tidak baik dengan persentase rata-rata 5\%. Pada dimensi Sasaran Kerja Pegawai (SKP) menunjukkan bahwa masih banyak pegawai yang belum memanfaatkan waktu bekerja secara optimal sehingga belum mampu mencapai target kerja dengan tepat waktu. Sedangkan pada dimensi Perilaku Kerja (PK) menunjukkan bahwa integritas pegawainya belum optimal, dimana masih banyak pegawai yang menunjukkan etika yang kurang baik seperti merokok di ruangan kerja padahal telah disediakan ruangan khusus untuk merokok.

Salah satu faktor yang mempengaruhi kinerja pegawai adalah karakteristik individu. Menurut Sopiah (2008:13), menyatakan bahwa setiap individu adalah unik, yang berbeda hanya antara individu yang satu dengan individu yang lain. Adapun dimensi karakteristik individu adalah ciri-ciri biografis, kepribadian, persepsi dan sikap.

Fenomena karakteristik individu pada Badan Pengelolaan Pajak dan Retribusi Daerah UPT SAMSAT Pematangsiantar dilhat dari dimensi kepribadian. Kepribadian pegawai yang berbeda-beda menjadikan pegawai mempunyai ciri khas tersendiri sehingga membentuk mempunyai ciri khas tersendiri sehingga membentuk suatu karakteristik individu pada pegawai. Baik buruknya karakteristik individu pegawai tergantung bagaimana mereka mengaplikasikannya. Dalam hal ini ditunjukkan bahwa pegawai yang satu dengan yang lain tidak saling berinteraksi dan tidak saling bekerjasama dalam melakukan kegiatan yang dilakukan, sehingga kegiatan yang dilakukan tidak berjalan sesuai dengan apa yang diharapkan dan pegawai belum mampu menafsirkan kesan dari pekerjaan yang dilakukan baik dari pegawai lama maupun pegawai baru. 
Selain karakteristik individu faktor lain yang dapat mempengaruhi kinerja pegawai adalah lingkungan kerja. Menurut Sedarmayanti (2009:21), yang mengatakan bahwa lingkungan kerja yang kondusif, baik dan nyaman dapat meningkatkan kinerja pegawai. Adapun dimensi lingkungan kerja, yaitu lingkungan kerja fisik dan lingkungan kerja non fisik.

Fenomena lingkungan kerja pada Badan Pengelolaan Pajak dan Retribusi Daerah UPT SAMSAT Pematangsiantar memiliki lingkungan kerja fisik yang baik, hal ini terlihat dari pusat kerja, kursi dan meja masih layak pakai, sehingga meningkatkan kinerja pegawai pada Badan Pengelolaan Pajak dan Retribusi Daerah UPT SAMSAT Pematangsiantar. Lingkungan kerja non fisik pada Badan Pengelolaan Pajak dan Retribusi Daerah UPT SAMSAT Pematangsiantar belum optimal, seperti hubungan kerjasama antar pegawai dimana masih ada pegawai yang tidak saling bekerjasama dalam menyelesaikan tugas yang diberikan sehingga dapat menyebabkan turunnya kinerja pegawai dalam organisasi dan dilihat dari keamanan di tempat kerja belum optimal, karena tingkat keamanan yang belum mendukung terciptanya suasana kerja yang aman.

Dari uraian di atas dapat dilihat adanya perbedaan harapan dan kenyataan serta dukungan teori yang menyatakan karakteristik individu dan lingkungan kerja mempengaruhi kinerja pegawai. Oleh karena itu penulis tertarik untuk melakukan penelitian.

\section{Rumusan Masalah}

a. Bagaimana gambaran karakteristik individu, lingkungan kerja dan kinerja pegawai pada Badan Pengelolaan Pajak dan Retribusi Daerah UPT SAMSAT Pematangsiantar.

b. Bagaimana pengaruh karakteristik individu dan lingkungan kerja terhadap kinerja pegawai pada Badan Pengelolaan Pajak dan Retribusi Daerah UPT SAMSAT Pematangsiantar baik secara simultan maupun parsial.

\section{Tujuan Penelitian}

a. Untuk mengetahui gambaran karakteristik individu, lingkungan kerja dan kinerja pegawai pada Badan Pengelolaan Pajak dan Retribusi Daerah UPT SAMSAT Pematangsiantar.

b. Untuk mengetahui pengaruh karakteristik individu dan lingkungan kerja terhadap kinerja pegawai pada Badan Pengelolaan Pajak dan Retribusi Daerah UPT SAMSAT Pematangsiantar baik secara simultan maupun parsial.

\section{Metode Penelitian}

Tempat penelitian dilakukan pada Badan Pengelolaan Pajak dan Retribusi Daerah UPT SAMSAT Pematangsiantar yang beralamat Jln. Sangnawaluh No. 37 A, Kelurahan Siopat Suhu, Kecamatan Siantar Timur Kota Pematangsiantar Kode Pos 21139. Populasi penelitian seluruh Pegawai Negeri Sipil (PNS) pada Badan Pengelolaan Pajak dan Retribusi Daerah UPT SAMSAT Pematangsiantar yang berjumlah 44 orang pegawai dan seluruhnya dijadikan sebagai sampel.

Desain penelitian adalah Penelitian Kepustakaan (Library Reseacrh) dan Penelitian Lapangan (Field Research). Teknik pengumpulan data berupa Kuesioner, Wawancara, dan Dokumentasi. Jenis data yang digunakan dalam penelitian ini yaitu data kualitatif dan kuantitatif. Hasil data yang diperoleh dari lapangan akan dianalisis secara deskriptif baik bersifat kualitatif dan kuantitatif.

\section{B. LANDASAN TEORI}

\section{Manajemen}

Manajemen merupakan proses pendayagunaan bahan baku dan sumber daya manusia untuk mencapai tujuan yang telah ditetapkan. Manajemen dikatakan baik apabila mampu mengatur orang-orang didalam perusahaan untuk dapat bekerja secara lebih baik sehingga tujuan perusahaan dapat tercapai. Menurut Griffin (2004:7), manajemen merupakan "suatu rangkaian aktivitas (termasuk perencanaan dan pengembalian keputusan, pengorganisasian, kepemimpinan dan pengendalian), yang diarahkan pada 
sumber-sumber daya organisasi (manusia, financial, fisik dan informasi), untuk mencapai tujuan organisasi dengan cara yang efektif dan efisien".

Menurut Handoko (2003:8), manajemen adalah "suatu proses perencanaan, pengorganisasian, pengarahan, dan pengendalian serta pengawasan kegiatan organisasi dan penggunaan sumber daya manusia lainnya agar tercapai tujuan organisasi". Sedangkan menurut Daft (2002:6), manajemen adalah "pencapaian tujuan organisasi dengan cara yang efektif melalui perencanaan, pengorganisasian, pengarahan, dan pengendalian sumber daya organisasi".

Berdasarkan pendapat ahli di atas, penulis menyimpulkan definisi tersebut dapat disimpulkan bahwa manajemen yaitu kegiatan dalam suatu organisasi yang meliputi perencanaan, pengorganisasian, pengambilan keputusan, pengendalian dan pengarahan pada sumber-sumber daya secara efektif dan efesien untuk mencapai tujuan organisasi.

\section{Manajemen Sumber Daya} Manusia

Manajemen sumber daya manusia memberi kontibusi terhadap pengembangan budaya kinerja tinggi. Dalam suatu organisasi, manajemen sumber daya manusia memiliki peran penting dalam mencapai tujuannya. Tanpa adanya sumber daya manusia, operasional suatu organisasi tidak dapat berjalan dengan lancar.

$\begin{array}{ccc}\text { Menurut Kaswan } & (2017: 3) \text {, } \\ \text { manajemen sumber daya manusia }\end{array}$ merupakan kebijakan, praktik maupun sistem yang mempengaruhi perilaku, sikap, dan kinerja pegawai atau orang-orang yang ada di dalam organisasi”. Menurut Zainal, et. al. (2015:10), manajemen sumber daya manusia adalah "salah satu bidang dari manajemen umum yang meliputi segi-segi perencanaan, pengorganisasian, pelaksanaan dan pengendalian". Sedangkan menurut Sutrisno (2011:7), manajemen sumber daya manusia adalah "suatu perencanaan, pengorganisasian, pengarahan, dan pengawasan pengadaan, pengembangan, kompensasi, pengintegrasian, pemeliharaan dan pemutusan hubungan kerja dengan maksud untuk mencapai tujuan organisasi perusahaan secara terpadu".

Berdasarkan pendapat ahli di atas, disimpulkan bahwa manajemen sumber daya manusia adalah manusia yang rancangan sistem-sistem formal berupa proses perencanaan, pengorganisasian, pengarahan, dan pengawasan atas pengadaan, pengembangan, pemberian kompensasi, pengintegrasian, pemeliharaan dan pemutusan hubungan kerja untuk mencapai tujuan organisasi perusahaan secara terpadu.

\section{Karakteristik Individu}

Sumber daya yang terpenting dalam suatu organisasi adalah sumber daya manusia, orang-orang yang memberikan tenaga, bakat, kreativitas dan usaha mereka kepada organisasi agar saat organisasi dapat tetap eksistensi. Setiap manusia mempunyai karakteristik individu yang bermacammacam antara yang satu dengan yang lainnya.

Menurut Tampubolon (2008:27), karakteristik individu adalah "individu seutuhnya (the whole person) memiliki kebutuhan fisiologis yang sama, tetapi tidak akan sama dalam memenuhi kebutuhan psikologis, disebabkan oleh latar belakang yang berbeda-beda (kogniif, afektif, serta psikomotorik)". Menurut Sopiah (2008:11), karakteristik individu adalah "ciri-ciri biografis, kepribadian, persepsi dan sikap". Sedangkan menurut Rahman (2013:77), karakteristik individu adalah "ciri khas yang ditunjukkan perbedaan seseorang tentang motivasi, inisiatif, kemampuan untuk tetap tegar menghadapi tugas atau memecahkan masalah atau bagaimana menyesuaikan perubahan yang baik dengan lingkungan yang mempengaruhi kinerja individu".

Berdasarkan pendapat ahli di atas, disimpulkan bahwa karakteristik individu adalah karakter seseorang individu yang mempunyai sifat dan ciri khas yang ditunjukkan perbedaan seseorang tentang motivasi, inisiatif, kemampuan untuk tetap tegar menghadapi tugas sampai tugas atau memecahkan masalah berbeda dalam memenuhi kebutuhan. 


\section{Lingkungan Kerja}

Lingkungan kerja yang baik dalam organisasi merupakan salah satu faktor yang cukup penting dalam upaya peningkatan kinerja pegawai. Lingkungan kerja yang nyaman dan kondusif memberikan rasa aman dan memungkinkan para pegawai untuk dapat bekerja optimal.

Menurut Sedarmayanti (2011:21), lingkungan kerja adalah "keseluruhan alat perkakas dan bahan yang dihadapi, lingkungan sekitarnya dimana seseorang bekerja, metode kerjanya, serta pengaturan kerjanya baik sebagai perorangan maupun sebagai kelompok". Menurut Sonny dalam Kaswan (2017:568), lingkungan kerja adalah "segala sesuatu yang ada di sekitar pekerja dan dapat mempengaruhi dirinya dalam menjalankan tugas yang dibebankan". Sedangkan menurut Mangkunegara (2017:105), lingkungan kerja adalah "segala aspek fisik kerja, psikologis kerja dan peraturan kerja yang dapat mempengaruhi kepuasan kerja dan pencapaian produktivitas sehingga menghasilkan kinerja yang tinggi bagi pegawai”.

Berdasarkan pendapat ahli di atas, maka penulis menyimpulkan bahwa lingkungan kerja adalah segala aspek fisik kerja yang ada disekitar para pekerja untuk melakukan pekerjaan yang telah ditetapkan sesuai peraturan kerja yang mempengaruhi kepuasan kerja dan pencapaian produktivitas.

\section{Kinerja Pegawai}

Kata kinerja merupakan terjemahan dari bahasa inggris yaitu dari kata performance berasal dari kata to perfrom yang berarti menampilkan atau melaksanakan. Performance berarti prestasi kerja, pelaksanaan kerja, pencapaian kerja, unit kerja atau penampilan kerja. Menurut
mengemukakan
kinerja $\begin{gathered}(2012: 231) \text {, } \\ \text { (performance) }\end{gathered}$ adalah "hasil pekerjaan yang dicapai seseorang berdasarkan persyaratanpersyaratan pekerjaan (job requirement)". Menurut Zainal, et. al. (2015:132), kinerja pegawai merupakan "hasil kerja yang telah dilaksanakan oleh pegawai untuk mencapai tujuan organisasi, jika kinerja pegawai tidak optimal maka tujuan suatu organisasi tidak tercapai". Sedangkan menurut Mondy (2008:256), kinerja merupakan "proses berorientasi tujuan yang diarahkan untuk memastikan bahwa proses-proses keorganisasian ada pada tempatnya untuk memaksimalkan produktivitas pegawai dan akhirnya organisasi”.

Berdasarkan pendapat ahli di atas, penulis menyimpulkan bahwa kinerja adalah hasil kerja yang dicapai oleh seorang pegawai dalam suatu organisasi dalam melakukan tugas yang diberikan sesuai dengan tanggungjawab yang diberikan.

\section{PEMBAHASAN}

\section{Analisis}

\section{a. Deskriptif Kualitatif}

Analisis deskriptif kualitatif dimaksudkan untuk mendapatkan gambaran atau deskripsi mengenai tanggapan dari pegawai mengenai pengaruh karakteristik individu dan lingkungan kerja terhadap kinerja pegawai pada Badan Pengelolaan Pajak dan Retribusi Daerah UPT SAMSAT Pematangsiantar. Sesudah pengujian data maka langkah selanjutnya peneliti melakukan pengkajian analisis kualitatif sebagai gambaran fenomena dari variabel penelitian pada saat sekarang ini.

Adapun penetapan kriteria nilai ratarata jawaban dari responden tersebut dimasukkan ke dalam kelas-kelas interval dimana penentuan intervalnya memakai rumus sebagai berikut:

Tabel 2

Nilai Interval dan Kategori Jawaban Responden

\begin{tabular}{|c|c|c|c|}
\hline \multirow{2}{*}{$\begin{array}{c}\text { Nilai } \\
\text { Interval }\end{array}$} & $\begin{array}{c}\text { Karakteri } \\
\text { stik } \\
\text { Individu }\end{array}$ & $\begin{array}{c}\text { Lingkungan } \\
\text { Kerja }\end{array}$ & $\begin{array}{c}\text { Kinerja } \\
\text { Pegawai }\end{array}$ \\
\hline $\begin{array}{c}1,00- \\
1,80\end{array}$ & $\begin{array}{c}\text { Sangat } \\
\text { Rendah }\end{array}$ & $\begin{array}{c}\text { Sangat } \\
\text { Tidak Baik }\end{array}$ & $\begin{array}{c}\text { Sangat } \\
\text { Tidak } \\
\text { Baik }\end{array}$ \\
\hline $\begin{array}{c}1,81- \\
2,60\end{array}$ & Rendah & Tidak Baik & $\begin{array}{c}\text { Tidak } \\
\text { Baik }\end{array}$ \\
\hline $\begin{array}{c}2,61- \\
3,40\end{array}$ & Sedang & Cukup Baik & $\begin{array}{c}\text { Cukup } \\
\text { Baik }\end{array}$ \\
\hline $\begin{array}{c}3,41- \\
4,20\end{array}$ & Tinggi & Baik & Baik \\
\hline $\begin{array}{c}4,21- \\
5.00\end{array}$ & $\begin{array}{c}\text { Sangat } \\
\text { Tinggi }\end{array}$ & $\begin{array}{c}\text { Sangat } \\
\text { Baik }\end{array}$ & $\begin{array}{c}\text { Sangat } \\
\text { Baik }\end{array}$ \\
\hline
\end{tabular}

Sumber: hasil pengolahan data (2018) 
1) Gambaran Karakteristik Individu Pegawai pada Badan Pengelolaan Pajak dan Retribusi Daerah UPT SAMSAT Pematangsiantar

Dari tabel 2 di atas, dapat dilihat bahwa dimensi ciri-ciri biografis pada indikator karakteristik dibentuk atas dasar usia diperoleh nilai rata-rata 3,82 dengan kriteria jawaban tinggi, dikarenakan di Badan Pengelolaan Pajak dan Retribusi Daerah UPT SAMSAT Pematangsiantar ditetapkan sebagai Pegawai Negeri Sipil (PNS) sesuai dengan usia yang cocok dan tepat saat ditetapkan sebagai PNS. Pada indikator karakteristik dibentuk atas dasar jumlah tanggungan diperoleh nilai rata-rata 3,84 dengan kriteria jawaban tinggi, dikarenakan Pegawai Negeri Sipil (PNS) Badan Pengelolaan Pajak dan Retribusi Daerah UPT SAMSAT Pematangsiantar sudah menerima kompensasi yang sesuai sehingga mereka mampu memberi tanggungjawab terhadap jumlah tanggungan yang diberikan.

Pada indikator karakteristik dibentuk atas masa kerja diperoleh nilai rata-rata 3,98 dengan kriteria jawaban tinggi, hal ini dikarenakan pegawai merasa tepat untuk menjalankan masa kerja yang ditetapkan. Dilihat dari dimensi kepribadian pada indikator interaksi antar rekan kerja diperoleh nilai rata-rata 3,36 dengan kriteria jawaban sedang, hal ini dikarenakan pegawai tidak sering melakukan tukar pikiran, tidak saling kerja sama dengan pimpinan dalam pekerjaan maupun sebaliknya. Pada indikator tingkah laku dalam bekerja diperoleh nilai rata-rata 3,73 dengan kriteria jawaban tinggi, hal ini dikarenakan pegawai dapat merespon sesuatu pekerjaan dengan baik. Pada indikator penyesuaian diri dengan lingkungan diperoleh nilai rata-rata 3,82 dengan kriteria jawaban tinggi, hal ini pegawai sudah mampu menyesuaikan diri jika ada pegawai baru yang menjadi bagian di kantor SAMSAT.

Kemudian dapat dilihat dimensi persepsi pada indikator memperhatikan arahan yang diberikan atasan diperoleh nilai rata-rata 3,84 dengan kriteria jawaban tinggi, hal ini dikarenakan pegawai sudah mampu memperhatikan arahan yang diberikan oleh atasan dalam melayani masyarakat untuk hal pengurusan STNKB (Surat Tanda Nomor Kendaraan Bermotor). Pada indikator proses mengorganisasikan kesan di kantor diperoleh nilai rata-rata 3,82 dengan kriteria jawaban tinggi, hal ini dikarenakan pegawai mampu mengatur ideide secara logis, berurutan dan tidak berteletele, ide yang disampaikan akan memuaskan kebutuhan-kebutuhan informasi. Pada indikator proses menafsirkan kesan di kantor diperoleh nilai rata-rata 3,68 dengan kriteria jawaban tinggi, hal ini dikarenakan pegawai mampu menafsirkan kesan dari pekerjaan yang dilakukan baik dari pegawai lama maupun pegawai baru.

Sedangkan dapat dilihat dimensi sikap pada indikator pemahaman terhadap lingkungan yang ada di kantor diperoleh nilai rata-rata 3,80 dengan kriteria jawaban tinggi, hal ini dikarenakan pegawai sudah mampu memahami kondisi fisik tempat kerja. Pada indikator pemahaman terhadap situasi yang ada di kantor diperoleh nilai rata-rata 3,73 dengan kriteria jawaban tinggi, hal ini dikarenakan instansi memiliki aturan dan budaya kerja masing-masing, sehingga jika terjadi sesuatu pegawai mampu mengandalkan insting khusus untuk menyikapinya. Pada indikator memahami rekan kerja yang ada di kantor diperoleh nilai rata-rata 3,72 dengan kriteria jawaban tinggi, hal ini dikarenakan pegawai mampu menghadapi karakter yang beraneka ragam dengan mengontrol emosi pada saat melakukan pekerjaan.

Secara keseluruhan dapat dilihat bahwa untuk total jawaban responden mengenai karakteristik individu diperoleh nilai rata-rata sebesar 3,76 dengan kriteria jawaban tinggi. Nilai rata-rata tertinggi sebesar 3,98 dengan kriteria jawaban tinggi pada dimensi ciri-ciri biografis dengan indikator karakteristik pegawai dibentuk atas dasar masa kerja. Sedangkan nilai ratarata terendah sebesar 3,36 dengan kriteria jawaban sedang pada dimensi kepribadian dengan indikator interaksi antar rekan kerja. 
2) Gambaran Lingkungan Kerja Pegawai pada Badan Pengelolaan Pajak dan Retribusi Daerah UPT SAMSAT Pematangsiantar

Dari tabel 2 di atas, dapat dilihat bahwa dimensi lingkungan fisik pada indikator kondisi lingkungan kerja diperoleh nilai rata-rata 3,59 dengan kriteria jawaban baik, dikarenakan pegawai merasa nyaman dengan bentuk ruangan yang sesuai untuk pegawai bekerja. Kemudian pada indikator kebersihan ruang kerja kantor diperoleh nilai rata-rata 3,59 dengan kriteria jawaban baik, hal ini dikarenakan kebersihan ruang kerja pada Badan Pengelolaan Pajak dan Retribusi Daerah UPT SAMSAT Pematangsiantar dari masing-masing ruangan pegawai selalu diperhatikan.

Kemudian pada indikator kelayakan peralatan kerja diperoleh nilai rata-rata 3,66 dengan kriteria jawaban baik, hal ini dikarenakan seluruh peralatan kantor masih baik dan masih layak pakai. Pada indikator fasilitas fisik yang tersedia berada dalam menjalankan tugas diperoleh nilai rata-rata 4,11 dengan kriteria jawaban baik, hal ini dikarenakan pemasangan Wifi dan Charging Box yang berada di ruang tunggu maupun peralatan lainnya yang berhubungan dengan pekerjaan sangat lengkap sehingga mendukung kinerja pegawai dalam menjalankan tugasnya. Selanjutnya pada indikator tingkat kebisingan ditempat kerja diperoleh nilai rata-rata 3,57 dengan kriteria jawaban baik, hal ini dikarenakan jarak area kantor yang terletak agak jauh dari jalan raya atau tempat keramaian lainnya, seperti suara kendaraan yang terlalu bising. Pada indikator kenyamanan ruang kerja berada pada rata-rata 3,98 dengan kriteria jawaban baik, hal ini disebabkan ruangan kerja yang bersih dan nyaman dengan adanya sirkulasi udara AC (Air Counditioner) sehingga udara disekitar tempat kerja tetap sehat. Pada indikator kemampuan pegawai dalam menyelesaikan pekerjaan secara tepat diperoleh nilai rata-rata 3,98 dengan kriteria jawaban baik, hal ini dikarenakan pegawai mampu menyelesaikan berkas-berkas secara tepat memberikan pelayanan kepada masyarakat dengan cepat dan tepat pada waktunya.

Pada indikator penerangan cahaya di tempat bekerja diperoleh nilai rata-rata 3,91 dengan kriteria jawaban baik, hal ini dikarenakan di setiap ruangan sudah dilengkapi cahaya dengan lampu yang cocok sehingga membuat mata nyaman untuk bekerja. Selanjutnya pada indikator keadaan ruangan di dalam kantor diperoleh nilai rata-rata 3,59 dengan kriteria jawaban baik, hal ini dikarenakan dinding/desain ruangan yang elegan. Sedangkan indikator kelengkapan kursi dan meja diperoleh nilai rata-rata 3,52 dengan kriteria baik, hal ini dikarenakan pegawai sudah memiliki kursi masing-masing untuk bekerja sehingga lebih mudah dan cepat dalam memberikan pelayanan.

Untuk dimensi lingkungan kerja non fisik pada indikator hubungan kerja sama pegawai dengan pimpinan diperoleh nilai rata-rata 3,52 dengan kriteria jawaban baik, hal ini dikarenakan pegawai sering melakukan tukar pikiran dengan pimpinan dalam pekerjaan maupun sebaliknya. Pada indikator hubungan kerja sama pegawai dengan kepala bagian diperoleh nilai ratarata 4,00 dengan kriteria jawaban baik, hal ini dikarenakan kepala bagian turut serta membantu pegawai menjalankan tugasnya apabila pegawai merasa kewalahan dalam melayani masyarakat.

Kemudian pada indikator hubungan pegawai dengan pegawai lain diperoleh nilai rata-rata 3,14 dengan kriteria cukup baik, hal ini dikarenakan pegawai kurang akrab dan tidak kompak dalam hal menyelesaikan pekerjaan. Pada indikator pengawasan yang dilakukan di tempat kerja diperoleh nilai rata-rata 3,95 dengan kriteria jawaban baik, hal ini dikarenakan kepala bagian sering memantau dan mengawasi pegawai dalam bekerja guna mencapai tujuan yang efektif dan efisien. Pada indikator suasana kerja di tempat kerja diperoleh nilai rata-rata 3,93 dengan kriteria jawaban baik, hal ini dikarenakan suasana yang nyaman dapat menimbulkan semangat pegawai dalam melakukan pekerjaan.

Pada indikator perlakuan pimpinan kepada pegawai di tempat pekerjaan 
diperoleh nilai rata-rata 3,55 dengan kriteria baik, hal ini dikarenakan pimpinan tidak pandang status maupun suku, agama dan ras kepada pegawai dalam hal memberikan pekerjaan kepada pegawai. Kemudian pada indikator keamanan di tempat kerja diperoleh nilai rata-rata 3,50 dengan kriteria baik, dikarenakan tingkat keamanan yang sedikit mendukung terciptanya suasana kerja yang aman.

Dari total jawaban responden mengenai dimensi lingkungan kerja fisik dan non fisik terdapat pada hasil rata-rata 3,71 dengan kriteria jawaban baik. Kemudian nilai rata-rata tertinggi sebesar 4,11 dengan kriteria jawaban baik pada indikator hubungan kerja sama dengan kepala bagian dan nilai terendah sebesar 3,14 dengan kriteria jawaban cukup baik pada indikator hubungan kerja sama pegawai dengan pegawai yang lain.

\section{3) Gambaran Kinerja Pegawai pada \\ Badan Pengelolaan Pajak dan \\ Retribusi Daerah UPT SAMSAT Pematangsiantar}

Pada tabel 2 di atas, dapat dilihat bahwa pada dimensi sasaran kerja pegawai dengan indikator kuantitas ketekunan diperoleh nilai rata-rata 4,18 dengan kriteria jawaban baik, dikarenakan pegawai dengan penuh ketekunan menyelesaikan berapapun jumlah setiap pekerjaan yang diterimanya. Pada indikator kuantitas pencapaian target kerja diperoleh nilai rata-rata 4,20 dengan kriteria jawaban baik, dikarenakan pegawai selalu berusaha mencapai target kerja dengan baik.

Pada indikator kualitas tingkat ketelitian diperoleh nilai rata-rata 4,02 dengan kriteria jawaban baik, dikarenakan pegawai teliti dalam melakukan setiap pekerjaannya sehingga dapat meminimalisir terjadinya kesalahan. Pada indikator kualitas tingkat mutu hasil kerja diperoleh nilai rata-rata 3,84 dengan kriteria jawaban baik, dikarenakan setiap pekerjaan yang dikerjakan oleh pegawai dilakukan dengan sungguh-sungguh.

Pada indikator ketepatan waktu diperoleh nilai rata-rata 3,32 dengan kriteria jawaban cukup baik, dikarenakan masih adanya pegawai yang kurang memanfaatkan waktu bekerja secara optimal sehingga belum mampu mencapai target kerja dengan tepat waktu. Pada indikator ketepatan waktu kehadiran dalam instansi diperoleh nilai rata-rata 3,95 dengan kriteria jawaban baik, dikarenakan adanya rasa tanggungjawab pegawai terhadap kehadiran akan menghasilkan kinerja yang baik bagi instansi.

Pada indikator anggaran yang dibutuhkan pegawai diperoleh nilai rata-rata 3,98 dengan kriteria jawaban baik, dikarenakan jumlah anggaran yang diberikan kepada pegawai sesuai dengan yang dibutuhkan untuk menyelesaikan pekerjaan. Pada indikator kemampuan mengalokasikan biaya diperoleh nilai ratarata 4,05 dengan kriteria jawaban baik, dikarenakan pegawai bisa memanfaatkan anggaran yang diberikan dengan baik.

Pada dimensi perilaku kerja dengan indikator tingkat pelayanan diperoleh nilai rata-rata 3,98 dengan kriteria jawaban baik, dikarenakan sebagai Pegawai Negeri Sipil (PNS) diharuskan memberikan pelayanan sebaik-baiknya kepada masyarakat sesuai dengan peraturan pemerintah. Pada indikator sikap dan perilaku dalam memberikan pelayanan diperoleh nilai ratarata 3,73 dengan kriteria jawaban baik, dikarenakan pegawai bersikap baik saat memberikan pelayanan kepada masyarakat.

Pada indikator etika pegawai diperoleh nilai rata-rata 3,36 dengan kriteria jawaban cukup baik, dikarenakan pegawai kurang memiliki etika yang baik dalam instansi. Pada indikator kemampuan dalam bertindak diperoleh nilai rata-rata 4,20 dengan kriteria jawaban baik, dikarenakan pegawai memiliki kemampuan bertindak seperti cepat tanggap dalam melakukan tugas yang ada.

Pada indikator komitmen yang bijaksana diperoleh nilai rata-rata 4,00 dengan kriteria jawaban baik, dikarenakan pegawai memiliki komitmen yang baik dalam bekerja dimana komitmen akan mendorong rasa percaya diri, dan semangat bekerja, menjalankan tugas menuju perubahan kearah yang lebih baik. Pada indikator kesediaan melakukan pekerjaan tanpa diperintah atasan diperoleh nilai rata- 
rata 3,86 dengan kriteria jawaban baik, dikarenakan pegawai memiliki kesadaran sendiri untuk mengerjakan segala sesuatunya tanpa harus diperintah dulu oleh atasan.

Pada indikator kewajiban melaksanakan tugas diperoleh nilai rata-rata 3,98 dengan kriteria jawaban baik, dikarenakan setiap pegawai mengerjakan kewajibannya untuk mengerjakan pekerjaan yang diberikan dan mendapatkan hasil yang memuaskan. Pada indikator pemberian sanksi diperoleh nilai rata-rata 4,16 dengan kriteria jawaban baik, dikarenakan pemimpin tidak pandang bulu dalam memberikan sanksi bagi pegawai yang melanggar peraturan.

Pada indikator kerjasama dengan rekan kerja diperoleh nilai rata-rata 3,95 dengan kriteria jawaban baik, dikarenakan para pegawai memiliki hubungan baik yang sudah lama terjalin yaitu sejak awal dimulai bekerja. Pada indikator hubungan dengan atasan diperoleh nilai rata-rata 4,18 dengan kriteria jawaban baik, dikarenakan pegawai selalu menjaga hubungan baik dengan atasan maupun sesama pegawainya.

Pada indikator pemimpin dalam mempengaruhi pegawai diperoleh nilai ratarata 4,18 dengan kriteria jawaban baik, dikarenakan pemimpin mempunyai kemampuan untuk mempengaruhi atau memotivasi pegawainya. Pada indikator pemimpin dalam menepatkan posisi pegawai diperoleh nilai rata-rata 4,02 dengan kriteria jawaban baik, dikarenakan pemimpin mampu mengelola dan menempatkan posisi pegawai dengan baik sesuai dengan keahlian yang dimiliki oleh pegawai masing-masing.

Secara keseluruhan dapat dilihat bahwa untuk total jawaban responden mengenai kinerja pegawai diperoleh nilai rata-rata sebesar 3,95 dengan kriteria jawaban baik. Nilai rata-rata tertinggi sebesar 4,20 dengan kriteria jawaban tinggi pada dimensi sasaran kerja pegawai dengan indikator kuantitas pencapaian target dan pada dimensi perilaku kerja dengan indikator kemampuan dalam bertindak. Sedangkan nilai rata-rata terendah sebesar 3,32 dengan kriteria jawaban cukup baik pada dimensi sasaran kerja pegawai dengan indikator ketepatan waktu.

\section{b. Deskriptif Kuantitatif}

\section{1) Analisa Regresi Linear Berganda}

Penelitian ini memiliki tujuan untuk menganalisis pengaruh karakteristik individu dan lingkungan kerja terhadap kinerja pegawai pada Badan Pengelolaan Pajak dan Retribusi Daerah UPT SAMSAT Pematangsiantar. Analisis data dalam penelitian ini menggunakan analisis regresi linier berganda. Analisis regresi linier berganda digunakan untuk mengetahui pengaruh variabel bebas $(\mathrm{X})$ dan variabel terikat (Y), dimana $\mathrm{X}$ adalah karakteristik individu dan lingkungan kerja dan $\mathrm{Y}$ adalah kinerja pegawai.

$$
\text { Analisis dijalankan dengan }
$$
menggunakan tabulasi jawaban responden pada kuesioner yang telah dijalankan.

$$
\text { Tabel } 3
$$

Hasil Regresi Linier Berganda

\begin{tabular}{|c|r|r|c|}
\hline \multirow{2}{*}{ Model } & \multicolumn{2}{|c|}{$\begin{array}{c}\text { Unstandardized } \\
\text { Coefficients }\end{array}$} & $\begin{array}{c}\text { Standardized } \\
\text { Coefficients }\end{array}$ \\
\cline { 2 - 4 } & \multicolumn{1}{|c|}{ B } & \multicolumn{1}{c|}{$\begin{array}{c}\text { Std. } \\
\text { Error }\end{array}$} & \multicolumn{1}{c|}{ Beta } \\
\hline (Constant) & $\mathbf{2 0 . 9 1 0}$ & 7.376 & \\
Karakteristi & $\mathbf{. 8 1 6}$ & .128 & .636 \\
k Individu & & & \\
(X1) & & & \\
Lingkungan \\
Kerja (X2) &. $\mathbf{3 9 9}$ & .109 & .312 \\
\hline
\end{tabular}

a. Dependent Variable: kinerja pegawai (Y)

Sumber: hasil pengolahan kuesioner menggunakan SPSS versi 21 (2018)

Berdasarkan hasil pengolahan data pada tabel 3 di atas, diperoleh model persamaan $\hat{\mathrm{Y}}=20,910+0,816 \mathrm{X}_{1}+$ $0,399 \mathrm{X}_{2}$, artinya terdapat pengaruh positif antara karakteristik individu dan lingkungan kerja terhadap kinerja pegawai pada Badan Pengelolaan Pajak dan Retribusi Daerah UPT SAMSAT Pematangsiantar.

\section{Koefisien Korelasi dan Koefisien Determinasi}

Analisa distribusi frekuensi jawaban responden menurut skor dari variabel $\mathrm{X}_{1}$ (karakteristik individu), $\mathrm{X}_{2}$ (lingkungan kerja) dan Y (kinerja pegawai) dimaksud sebagaimana telah dilakukan, hanyalah bermanfaat untuk memberikan informasi pendahuluan mengenai pola distribusi jawaban responden menurut skor. 
Selanjutnya, dilakukan perhitungan korelasi berupa derajat atau kedalaman hubungan fungsional yang menjelaskan hubungan antara perubah, dinyatakan dengan yang dinamakan korelasi yang sering disimbolkan dengan $\mathrm{r}$, nilai $\mathrm{r}$ dapat dihitung menggunakan SPSS versi 21. Hasil koefisien korelasi dan koefisien determinasi dapat dilihat pada tabel berikut ini:

Tabel 4

Hasil Koefisien Korelasi dan Koefisien Determinasi

\begin{tabular}{|l|c|r|r|r|}
\hline $\begin{array}{l}\text { Mod } \\
\text { el }\end{array}$ & $\boldsymbol{R}$ & $\begin{array}{c}\boldsymbol{R} \\
\text { Square }\end{array}$ & $\begin{array}{c}\text { Adjuste } \\
\text { d R } \\
\text { Square }\end{array}$ & $\begin{array}{l}\text { Std. Error of } \\
\text { the Estimate }\end{array}$ \\
\hline 1 & .799 $^{\mathrm{a}}$ & .639 & .621 & 7.522 \\
\hline
\end{tabular}

a. Predictors: (Constant), lingkungan kerja

(X2), karakteristik individu (X1)

b. Dependent Variable: kinerja pegawai (Y)

Sumber: hasil pengolahan kuesioner

menggunakan SPSS versi 21 (2018)

Dari hasil korelasi pada tabel 4 di atas diperoleh nilai $r=0,799$ yang artinya teradapat hubungan yang kuat dan positif antara karakteristik individu, lingkungan kerja dengan kinerja pegawai pada Badan Pengelolaan Pajak dan Retribusi Daerah UPT SAMSAT Pematangsiantar, sesuai dengan kriteria korelasi.

Kemudian diperoleh nilai koefisien determinasi $\mathrm{R}=0,639$, artinya baik tidaknya kinerja pegawai (Y) pada Badan Pengelolaan Pajak dan Retribusi Daerah UPT SAMSAT Pematangsiantar sebesar $63,90 \%$ dapat dijelaskan oleh karakteristik individu $\left(\mathrm{X}_{1}\right)$ dan lingkungan kerja $\left(\mathrm{X}_{2}\right)$ sedangkan sisanya sebesar $36,10 \%$ dipengaruhi oleh faktor lain seperti kepemimpinan, prestasi kerja, fasilitas, kompensasi, motivasi, pengembangan karir, kemampuan intelektual, gaya kepemimpinan, pelatihan, disiplin kerja dan variabel lain yang tidak diteliti dalam penelitian ini.

\section{Pengujian Hipotesis}

\section{1) Uji Simultan (Uji F)}

Pengujian ini dilakukan secara simultan yaitu dilakukan untuk menentukan diterima atau ditolaknya hipotesis, pengujian hipotesis dilakukan untuk mengetahui apakah variabel karakteristik individu dan lingkungan kerja yang diuji berpengaruh terhadap kinerja pegawai. Jika
$\mathrm{F}_{\text {hitung }}>\mathrm{F}_{\text {tabel }}$ atau signifikansi $\leq 0,05$ maka $\mathrm{H}_{0}$ ditolak. Untuk menguji kebenarannya maka dilakukan pengujian hipotesis dengan menggunakan aplikasi SPSS versi 21.

Tabel 5

Perkiraan Nilai $\mathbf{F}_{\text {hitung }}$

\begin{tabular}{|r|r|r|r|r|r|}
\hline Model & $\begin{array}{c}\text { Sum } \\
\text { of } \\
\text { Squar } \\
\text { es }\end{array}$ & Df & $\begin{array}{c}\text { Mean } \\
\text { Square }\end{array}$ & F & Sig. \\
\hline Regr & 4098.4 & 2 & 2049.201 & $\mathbf{3 6 . 2 1 4}$ & $\mathbf{. 0 0 0}$ \\
essio & 02 & & & & \\
$n$ & & & & & \\
1 Resi & 2320.0 & 41 & 56.586 & & \\
dual & 30 & & & & \\
Total & 6418.4 & 43 & & & \\
32 & & & & \\
\hline
\end{tabular}

a. Dependent Variable: Kinerja Pegawai (Y)

b. Predictors: (Constant), Lingkungan Kerja

(X2), Karakteristik Individu (X1)

Sumber: hasil pengolahan kuesioner menggunakan SPSS versi 21 (2018).

Berdasarkan tabel 5 diatas diperoleh nilai $F_{\text {hitung }}$ sebesar $36,214>F_{\text {tabel }}$ dengan $(0,05 ; 2$ vs 41$)$ sebesar 3,23 , atau dengan signifikan $0,000<\alpha 0,05$, maka $\mathrm{H}_{0}$ ditolak, artinya karakteristik individu dan lingkungan kerja berpengaruh positif dan signifikan terhadap kinerja pegawai pada Badan Pengelolaan Pajak dan Retribusi Daerah UPT SAMSAT Pematangsiantar.

\section{2) Uji Parsial (Uji t)}

Pengujian ini dilakukan secara parsial yaitu dilakukan untuk menentukan diterimanya atau ditolaknya hipotesis, pengujian hipotesis dilakukan untuk mengetahui apakah variabel karakteristik individu dan lingkungan kerja yang di uji berpengaruh terhadap kinerja pegawai. Jika $t_{\text {hitung }}>\mathrm{t}_{\text {tabel }}$ atau signifikansi $\leq 0,05{\text { maka } \mathrm{H}_{0}}$ ditolak. Untuk menguji kebenarannya maka dilakukan pengujian hipotesis dengan menggunakan program aplikasi SPSS versi 21.

Tabel 6

Perkiraan NIlai $t_{\text {hitung }}$

\begin{tabular}{|l|r|r|}
\hline \multicolumn{1}{|c|}{ Model } & \multicolumn{1}{c|}{$\boldsymbol{t}$} & \multicolumn{1}{c|}{ Sig. } \\
\hline (Constant) & 2.835 & .007 \\
$\quad \begin{array}{l}\text { Karakteristik Individu } \\
1 \text { (X1) }\end{array}$ & $\mathbf{6 . 3 5 8}$ & $\mathbf{. 0 0 0}$ \\
$\quad \begin{array}{l}\text { Lingkungan Kerja } \\
\text { (X2) }\end{array}$ & $\mathbf{3 . 1 2 2}$ & $\mathbf{. 0 0 3}$ \\
\hline
\end{tabular}


a. Dependent Variable: Kinerja Pegawai (Y) Sumber: hasil pengolahan kuesioner menggunakan SPSS versi 21 (2018).

Berdasarkan tabel 6 di atas, diperoleh nilai $t_{\text {hitung }}$ pada variabel $\mathrm{X}_{1}$ (karakteristik individu) sebesar 6,358 $>\mathrm{t}_{\text {tabel }}$ dengan $\mathrm{df}=$ n-k-1 (44-2-1=41) sebesar 2,019 atau taraf signifikan $0,000<\alpha 0,05$, maka $\mathrm{H}_{0}$ ditolak, artinya karakteristik individu berpengaruh positif dan signifikan terhadap kinerja pegawai pada Badan Pengelolaan Pajak dan Retribusi Daerah UPT SAMSAT Pematangsiantar.

Kemudian nilai thitung pada variabel $\mathrm{X}_{2}$ (lingkungan kerja) sebesar 3,122 > dari t tabel dengan $\mathrm{df}=\mathrm{n}-\mathrm{k}-1, \quad(44-2-1=41)$ sebesar 2,019 atau taraf signifikan $0,003<\alpha 0,05$, maka $\mathrm{H}_{0}$ ditolak, artinya lingkungan kerja berpengaruh positif dan signifikan terhadap kinerja pegawai pada Badan Pengelolaan Pajak dan Retribusi Daerah UPT SAMSAT Pematangsiantar.

\section{KESIMPULAN DAN SARAN}

\section{Kesimpulan}

a. Hasil analisis deskriptif kualitatif tentang karakteristik individu berdasarkan dimensi ciri-ciri biografis, kepribadian, persepsi dan sikap memperoleh rata-rata jawaban keseluruhan 3,76 dengan kriteria jawaban tinggi. Kemudian nilai rata-rata tertinggi sebesar 3,98 dengan kriteria jawaban tinggi dengan indikator karakteristik pegawai dibentuk atas dasar masa kerja. Sedangkan nilai rata-rata terendah sebesar 3,36 dengan kriteria jawaban sedang pada dimensi kepribadian dengan indikator interaksi pegawai antar rekan kerja.

b. Hasil analisis deskriptif kualitatif tentang lingkungan kerja berdasarkan dimensi lingkungan kerja fisik dan lingkungan kerja non fisik diperoleh rata-rata 3,71 dengan kriteria jawaban baik. Kemudian rata-rata tertinggi sebesar 4,11 dengan kriteria jawaban baik pada dimensi lingkungan fisik dengan indikator fasilitas fisik yang tersedia dalam mendukung pegawai dalam menjalankan tugas. Sedangkan nilai rata-rata terendah sebesar 3,14 dengan kriteria cukup baik pada dimensi lingkungan non fisik indikator hubungan kerja sama pegawai dengan pegawai lain.

c. Hasil analisis deskriptif kualitatif tentang kinerja pegawai berdasarkan dimensi kualitas, kuantitas, waktu, biaya, orientasi pelayanan, integritas, komitmen, disiplin, kerja sama dan kepemimpinan memperoleh rata-rata jawaban keseluruhan sebesar 3,95 dengan kriteria jawaban baik. Kemudian nilai rata-rata tertinggi sebesar 4,20 dengan kriteria jawaban baik diperoleh nilai dimensi sasaran kerja pegawai dengan indikator tingkat pencapaian target kerja dan pada dimensi perilaku kerja dengan indikator kemampuan pegawai dalam instansi. Sedangkan nilai rata-rata terendah sebesar 3,32 dengan kriteria cukup baik terdapat pada dimensi kualitas dengan indikator pegawai dalam menyelesaikan pekerjaan dengan tepat waktu.

d. Hasil analisis diperoleh persamaan regresi linear berganda terdapat pengaruh yang positif antara karakteristik individu dan lingkungan kerja terhadap kinerja pegawai pada Badan Pengelolaan Pajak dan Retribusi Daerah UPT SAMSAT Pematangsiantar.

e. Hasil analisis korelasi terdapat hubungan yang kuat dan positif antara karakteristik individu, lingkungan kerja dengan kinerja pegawai pada Badan Pengelolaan Pajak dan Retribusi Daerah UPT SAMSAT Pematangsiantar. Kemudian diperoleh nilai koefisien determinasi baik tidaknya kinerja pegawai pada Badan Pengelolaan Pajak dan Retribusi Daerah UPT SAMSAT Pematangsiantar dapat dijelaskan oleh karakteristik individu dan lingkungan sedangkan sisanya dipengaruh oleh faktor lain yang tidak dibahas dalam penelitian ini kepemimpinan, prestasi kerja, fasilitas, kompensasi, motivasi, pengembangan karir, kemampuan intelektual, gaya kepemimpinan, pelatihan, disiplin kerja dan variabel lain yang tidak diteliti dalam penelitian ini.

f. Hasil pengujian hipotesis secara simultan dengan uji $\mathrm{F} \mathrm{H}_{0}$ ditolak, artinya terdapat pengaruh yang positif dan signifikan 
antara variabel karakteristik individu dan lingkungan kerja berpengaruh positif dan signifikan terhadap kinerja pegawai pada Badan Pengelolaan Pajak dan Retribusi Daerah UPT SAMSAT Pematangsiantar.

g. Hasil pengujian hipotesis secara parsial untuk variabel karakteristik individu dengan perolehan uji t $\mathrm{H}_{0}$ ditolak, artinya terdapat pengaruh yang positif dan signifikan antara variabel karakteristik individu terhadap kinerja pegawai pada Badan Pengelolaan Pajak dan Retribusi Daerah UPT SAMSAT Pematangsiantar. Kemudian pengujian hipotesis secara parsial untuk lingkungan kerja dengan perolehan uji $\mathrm{t} \mathrm{H}_{0}$ ditolak, artinya terdapat pengaruh yang positif dan signifikan antara lingkungan kerja terhadap kinerja pegawai pada Badan Pengelolaan Pajak dan Retribusi Daerah UPT SAMSAT Pematangsiantar.

\section{Saran}

a. Untuk lebih memperbaiki karakteristik individu setiap pegawai sebaiknya dapat menilai karakternya masing-masing. Pegawai Badan Pengelolaan Pajak dan Retribusi Daerah UPT SAMSAT Pematangsiantar sebaiknya menjalin hubungan yang baik, melakukan komunikasi secara terbuka, lebih mengutamakan kerja sama tim demi produktivitas kerja.

b. Untuk lebih memperbaiki lingkungan kerja, Pegawai Badan Pengelolaan Pajak dan Retribusi Daerah UPT SAMSAT Pematangsiantar sebaiknya menumbuhkan sikap saling menghargai dan menghormati terhadap sesama pegawai sehingga terciptanya hubungan kerja sama yang baik dan solid.

c. Untuk lebih meningkatkan kinerja pegawai Badan Pengelolaan Pajak dan Retribusi Daerah UPT SAMSAT Pematangsiantar, pemimpin sebaiknya memberikan pengarahan kepada pegawai untuk memanfaatkan waktu bekerja demi terciptanya pelayanan yang baik kepada masyarakat dalam hal pengurusan pajak kendaraan bermotor.

d. Sehubungan dengan keterbatasanketerbatasan yang ada pada penulis, penelitian ini masih terdapat kelemahankelemahan dan belum dapat mengungkap seluruh variabel yang dapat mempengaruhi kinerja pegawai pada Badan Pengelolaan Pajak dan Retribusi Daerah UPT SAMSAT Pematangsiantar. Sebagai bahan masukan untuk penelitian selanjutnya, perlu memperbanyak variabel penelitian, seperti budaya organisasi, komunikasi, kompensasi, kemampuan intelektual, gaya kepemimpinan, pelatihan dan pengembangan karir, kepuasan kerja dan kompetensi pegawai, fasilitas dan variabel lain yang tidak diteliti dalam penelitian ini.

\section{E. DAFTAR PUSTAKA}

Abdul Rahman, Agus. 2013. Psikologis Sosial: Integritasi Pengetahuan Wahyu dan Pengetahuan Empirik. Jakarta: Rajawali Pers.

Ardana, Komang, Niwayan Mujiati dan Anak Agung Ayu Sriathi. 2009. Perilaku Organisasi. Yogyakarta: Graha Ilmu.

Bangun, Wilson. 2012. Manajemen Sumber Daya Manusia. Jakarta: Penerbit Erlangga.

Daft, Richard L. 2002. Manajemen. Edisi V, Jilid I. Jakarta: Erlangga.

Griffin, Ricky. W. 2004. Manajemen. Edisi VII, Jilid I. Jakarta: Erlangga.

Handoko, T. Hani. 2003. Manajemen. Edisi II. Yogyakarta: BPFE.

Kaswan. 2017. Psikologi Industri dan Organisasi. Edisi I. Bandung: Alfabeta.

Mangkunegara, A.A. Anwar Prabu. 2017. Manajemen Sumber Daya Manusia Perusahaan. Bandung: PT Remaja Rosdakarya.

Mathis, Robert L. dan John H. Jackson. 2006. Human Resource Manajement (Manajemen Sumber Daya Manusia). Edisi X. Jakarta: Salemba Empat.

Mondy, R wayne. 2008. Manajemen Sumber Daya Manusia. Edisi X, Jilid 1. Jakarta: Erlangga. 
Robbins, Stephen P. dan Mary Coulter. 2010. Manajemen. Edisi X. Jakarta: Penerbit Erlangga.

Robbins Stephen $\mathrm{P}$ dan Timothy A Judge. 2008. Perilaku Organisasi. Edisi XII, Jilid I. Jakarta: Salemba Empat.

Robbins, Stephen P. 2002. Prinsip-prinsip Perilaku Organisasi. Edisi V. Jakarta: Erlangga.

Sedarmayanti. 2017. Manajemen Sumber Daya Manusia, Reformasi Birokrasi dan Manajemen Pegawai Negeri Sipil. Edisi V. Bandung: PT Refika Aditama.

Sedarmayanti. 2011. Tata Kerja dan Produktivitas Kerja. Jakarta: CV Mandar Maju

Siagian, Sondang. 2015. Manajemen Sumber Daya Manusia. Bumi Aksara: Jakarta.

Simamora, Henry, 2004. Manajemen Sumber Daya Manusia. Edisi III. Yogyakarta. Penerbit: STIE YKPN.

Simbolon, Hotman. 2009. Statistika. Yogyakarta: Graha Ilmu.

Sopiah. 2008. Perilaku Organisasi. Malang. Andi Offset.

Sugiyono. 2017. Metode Penelitian Kuantitatif, Kualitatif dan R \& D. Bandung: Alfabeta.

Sule, Ernie Tisnawati dan Kurniawan Saefullah. 2009. Pengantar Manajemen. Salemba Empat. Jakarta.

Sutrisno, Edy. 2011. Budaya Organisasi. Edisi I, Jilid I. Jakarta: Kencana Prenada Media Group.

Tampubolon, Manahan P. 2008. Perilaku Keorganisasian. Bogor. Ghalia Indonesia.

Thoha, Miftah. 2012. Kepemimpinan dan Manajemen. Edisi I. Jakarta: PT Raja Granfindo.

Zainal, Veithzal Rivai, et. al. 2015. Manajemen Sumber Daya Manusia Untuk Perusahaan. Jakarta: PT Raja Grafindo Persada. 